\title{
An Analysis of English Oral Communication Apprehension and Anxiety of Engineering Undergraduates in Pakistan
}

\author{
Muhammad Arif Soomro ${ }^{1}$, Insaf Ali Siming ${ }^{1}$, Mansoor Ahmed Channa ${ }^{1}$, Syed Hyder Raza $\mathrm{Shah}^{2}$, Nadeem \\ Naeem ${ }^{1} \&$ Abdul Malik Abbasi ${ }^{3}$ \\ ${ }^{1}$ Quaid-e-Awam University of Engineering, Science, and Technology, Nawabshah-Sindh, Pakistan \\ ${ }^{2}$ School of English, Shaheed Benazir Bhutto University, Sanghar Campus, Pakistan \\ ${ }^{3}$ Sindh Madressatul Islam University, Karachi, Pakistan \\ Correspondence: Muhammad Arif Soomro,Quaid-e-Awam University of Engineering, Science, and Technology, \\ Nawabshah, Pakistan. E-mail: muhammadarif@quest.edu.pk
}

Received: November 13, 2018 Accepted: December 19, 2018 Online Published: February 24, 2019

doi:10.5539/ijel.v9n2p162 URL: https://doi.org/10.5539/ijel.v9n2p162

\begin{abstract}
This paper investigates the communication apprehension (CA) and a form of anxiety which affects the engineering undergraduates' oral communicative skills in English and particularly in oral presentations. However, this study was mainly based on the research question to be investigated: What barriers prevail among undergraduates that handicap their successful language learning and oral communicative skills in English? This study used qualitative instruments for collecting data; the instruments used were included as semi-structured interviews with eight participants and two focus group discussion to explore the barriers among Pakistani undergraduates. The data were analyzed using content analysis of the gathered data. The results revealed that communication apprehension can cause the variety of barriers among undergraduates during oral presentation. The results provided positive insights to communication practitioners and language educators on the issues related to communication apprehension; therefore, certain measures need to be taken to surmount the identified barriers.
\end{abstract}

Keywords: oral communication apprehension, oral skills, oral presentation, engineering-undergraduates

\section{Introduction}

In past, a great amount of research has accumulated regarding the contexts and prevalence of communication apprehension (CA). The phenomenon was introduced by McCroskey's (1970) conceptualisation of CA as fear or anxiety associated with either real or anticipated communication with another person(s). Similarly, communication scholars, practitioners, and corporate investigated the re-conceptualized and multi-contextualized CA; hence, this study has close connections with the previous studies but this has been contextualized in Pakistan where oral communication skills in English are needed for both performing services and especially for everyday jobs responsibilities as well as promotions. Effective oral communicative skills are of great vitality for career development. No doubt, learning a foreign language is not easy task (Hassan, 2009), especially if learners are in non-native country. Pakistan is multilingual society divided in rural and urban communities. This difference is based on various cultural and social factors range from lack of proper facilities to the right of basic human needs of life. Language learning is measured in term of learners' ability to exchange ideas through conversation, social interactions, group discussion, and oral presentations with interlocutors in the target language (Nunan, 1991; Khan, 2010; Richards \& Renandya, 2002; Lindsay \& Knight, 2006; Ellis, 2003), yet, mastering oral communication skills seem to be a challenging to develop (Jamshidnejad, 2010, 2011; Ya-ni, 2007) in a target language context, despite of many efforts taken in the development of teaching methodologies and approaches. In this study, oral communication skills refer to the group discussion, conversation, social interactions, and oral presentations with ability to communicate fluently and effectively in English language.

\subsection{Research Purpose}

The main purpose of this study is to explore the presence of communication apprehension among Pakistani undergraduates and what are the main barriers that prevail among undergraduates and why? The purpose of this research is to better understand the reasons which contribute to ineffective oral communication (especially 
among Pakistani engineering undergraduates) and to find ways to enable them to overcome their barriers. This present study remained within oral presentations.

\subsection{Background}

This study is conducted in one engineering university (one of the public sector institutions of higher education) in Pakistan. Moreover, the faculty members in this institution teach subjects including Writing and Communication Skills, Functional English, and Technical Report Writing and Presentation Skills in different disciplines as the compulsory subject based on either 3 credit hours or 2 credit hours offered by the institution. The undergraduate learners of English at this engineering university in Pakistan cope with oral communicative skills in English. Each undergraduate is required to take and pass these courses, in order to meet the university's degree requirement. The courses offered a variety of contents based on the receptive and productive skills which aim to improve and enable undergraduates' overall English language proficiency. Therefore, this study is designed to explore the presence of communication apprehension and its reasons among undergraduates while dealing oral presentations in English.

\subsection{Scope of Research}

This study was designed to explore the presence of communication apprehension among Pakistani engineering undergraduates during their oral communicative activities, broadly in four dimensions: group discussion, conversation, social interactions, and oral presentations. After the respondents' feedback regarding four oral communication dimensions; the current study is further delimited to only oral presentations.

\section{Review of Literature}

\subsection{Oral Communication Skills Defined}

Oral communication skills (OCs) can be defined as face-to-face communication, person to group communication, pair or group discussion, telephonic conversation, interviews and meetings, speech at conference or seminars, and negotiation. The selection of oral skills depends on the purpose and necessities of communication (Ang, 2004; Brooks \& Heath, 1993; Bryne, 1986; Ahmed, 2013). The current study has major focus on the oral presentation.

\subsection{Need of Oral Communication Skills (OCs) in English}

Need of oral communication skills in English had immensely increased to perform daily routine tasks in academia life and professional career. Excellence at English proficiency matters more in global economy; it matters greatly to companies as well (TIRF, 2009). English has developed its own momentum, due to abundance of technological advancements and growing social interactions within the connected world in which many languages could have not achieved a prime position around the globe (Asuncion-Lade, 1998; Reimer, 2007; Kitao, 1996). Despite such vast spread and need of oral communication skills around the globe, Brown and Yule (1983) found that English language learners admit that they lack oral skills and there is a need of oral presentation, a leading need of contemporary students (Yasmin, 2003). Richard (2006) emphasized the grown demand for English effective communication skills; students should acquire 'soft skills' which is known as the ability to be sociable and communicative for sharing their opinions to supplement their 'hard skills' (New Straits Times, 2007; Morreale et al., 2000; Staab, 1992). Evidently, speaking is the basic requirement of effective oral skills which is considered as a royal road for excellence and development of academia and professional life (Baum, 2000).

\subsection{Factors in Communication Apprehension Among Students}

Hundreds of studies have comprehensively studied the problems in oral communication (Du-Babcock, 2000; Xu \& Babcock, 2012; Mortensen, 1972; Bhattacharyya et al., 2009; Kassim et al., 2010; Verapornvanichkul, 2011; Khan \& Ali, 2009). Thaher (2005) these studies classified the factors that lead to CA among students into three categories: (i) psychological factors, (ii) instructional factors, (iii) socio-cultural factors. The present study focused on the psychological factors, which include emotion, anxiety, self-esteem, fear, attitude, and motivation. Oral communication apprehensive factors have been covered in wide range that includes shyness, stage fright, speech anxiety, and others (Asker, 1998; Lucas, 2001; Vitasari et al., 2010; Margarita, 2008; Aly \& Islam, 2005).

With regard to prior research studies, Tunaboylu (1993) asserted that students' tendency to be passive listener rather than active speaker in oral communicative activities in English which is because of communication apprehension; most frequent factor is psychological pressure which results in making mistakes due to the presence of their class fellows. The other factors include poor count of vocabulary; consequently, communication apprehension is a factor that contributes to students' fear of poor communication and more negative 
repercussions (Singh et al., 2011; Price, 1991; Frantz et al., 2005; Brozi \& Mills, 2001). McCroskey et al. (1999) assessed levels of CA among Japanese in native and second language (English), the results indicated that Japanese students had high CA in both languages. In essence, students' shortage of vocabulary, unfamiliarity with target language, mispronunciation, and L1 interference are amongst the major oral communication barriers (Alyan, 2013). Based on the review of literature, the following main questions are put forth to explore the overall presence of communication apprehension and its reasons among Pakistani undergraduates to be investigated in line with the following research questions.

RQ1: Does Communication apprehension prevail among Pakistani undergraduates and how does it hinder undergraduates' performance during oral presentation?

RQ2: What are the perceived barriers of Pakistani undergraduates that hinder oral presentation effectiveness in English?

\section{Research Methods}

This present study is an exploratory research based on empirical-theoretical framework, taking epistemological position as a qualitative method. Focus group discussion can be employed to explore insights into a variety of phenomenon (Gubrium \& Holstein, 2001; Rubin \& Rubin, 1995). During the qualitative data collection, a focus group discussion was conducted with eight participants; for each focus group, the researchers attempted to schedule eight individuals, a number representing the ideal modal recommended in the literature for group size (Guest, Namy, \& Mitchell, 2013; 2017; Lunt \& Livingstone, 1996; Adams \& Cox, 2008). For participants' convenience, the native language was allowed to be undertaken which was later translated into English. All the data were recorded into two digital devices a mobile phone and laptop audio recorders to prevent from any data loss. A note taker (neutral observer) was invited to note key themes that were frequently said by the respondents during discussion. Expected time for discussion was estimated no longer than forty-five minutes, as discussion started was lasted after one and half hour interestingly.

\section{Data Analysis}

There were two focus groups in discussions and eight participants for interviews. A briefing session was conducted prior to conduct of semi-structured interviews and focus group discussion and participants were provided informed consent. Due the similarity in findings of both data were transcribed, interpreted and presented together manually by the researchers. For participants' convenience native language was allowed, later was translated into English. All the data were recorded into two digital devices a mobile phone and a laptop audio recorder to prevent from any data loss. Once all gathered audio-recorded data of focus group discussion was completed, and transcribed verbatim through Express Scribe Transcription Software (http://www.nch.com.au/scribe/). Transcription is the process of word-by-word recording of data into written form so that the research can be undertaken coherently and can be linked with analytic coding (Stuckey, 2014). Deductive-coding was conducted by using prior categories taken from literature; inductive-coding was also employed to identify the key concepts that formulate the categories as the emergence from gathered data (Kang $\&$ Cheng, 2013 p. 174). Focus group discussions were transcribed in MSWord document and printed for analysis. For analysis purposes, frequency of responses regarding specific idea were considered to identify the main barriers as suggested by Krueger (1994), in focus group discussion, the percentages of findings are seen not suitable to give (Kitzinger, 1995). Data were analysed manually, after data cleansing. Anderson (1990) has guided for data analysis in this kind of approach that is searching for repetitive and big themes and making a list of themes that were stated most frequently by participants, keeping in view the contextual consideration of words and their usage. The preference is given to both combinations of summaries with actual quotes (verbatim) that express the participants' point of view in their actual uttered words.

\section{Findings and Interpretation}

Findings showed that perceived barriers affecting undergraduates' oral presentation can be defined into three main categories: psychological barriers, social barriers, and linguistic barriers. As shown in Table 1, the category that most of undergraduates mentioned as the most common barriers are psychological, social barriers and linguistic barriers based on the frequency of responses. However, twelve barriers emerged as the most often in the gathered data. 
Table 1. Categories and perceived barriers based on frequency of responses

\begin{tabular}{ll}
\hline Category & Perceived Barriers \\
\hline Psychological & 1) Peer pressure \\
& 2) lacked self-confidence \\
& 3) anxiety \\
& 4) hesitation \\
& 5) inferiority complex \\
Social & 1) lacked interest \\
& 2) inadequate educational background \\
& 3) lacked environment \\
4inguistic & 1) Lowfamiliar audience \\
& 2) lack of knowledge \\
& 3) English as a barrier \\
\hline
\end{tabular}

\subsection{Psychological Perceived Barriers}

\subsubsection{Peer Pressure}

Among engineering undergraduates, peer pressure has affected their oral communicative skills specifically oral presentations in different ways. This barrier was discussed by the participants and they shared that they go under pressure due to English language. Their collective response was:

"Peer pressure, is our one of problems certainly, our problem remains while communication with someone who are of our age, during classes. I don't face such as while communicating with relatives but I feel tension and pressure during class presentations." (6/8).

Most participants insisted as one of them a voiced concern, as "level of speaker in one factor" which is a problem contributing factor while delivering oral presentation. This barrier for the participants was explored as a common theme, as the participants below opined:

“...there are many reasons of anxiety such as level of speaker (peer pressure and of superior pressure) is one factor." (5/8).

\subsubsection{Lacked Self-Confidence}

Second common shared barrier by the participants that they lacked confidence. Various interesting responses were given as one of the participants said as:

“...environment comes later but the first thing is that; here students are facing problems due to confidence. Teachers should give stimuli or reward in order to create environment of English speaking in this way students will be motivated." (6/8).

For undergraduates, environment comes later what comes first is self-confidence. One of the participants expressed his disappointment that "students are facing problem due to self-confidence", later comes English speaking environment problem. Throughout discussion, most of the participants shared, how problematic it is for them if one loses self-confidence during oral presentations. Participants repeated that low self-confidence affected their communicative skills. One of them shows his frustration as:

“...sometimes, I cannot communicate ideas due to low confidence and I feel disappointed.” (1/8).

Similarly, other participant found it as a general barrier that is faced by the most of undergraduates during oral presentations. Most participants considered it as the main barrier to oral presentation effectiveness. One participant echoed:

"...confidence level is lower because we have no proper pronunciation and inappropriate usage of words...

I feel low confidence..., due to this problem I feel embarrassed." (6/8).

The other participants agreed that low self-confidence created barriers as "no proper pronunciation and misuse usage of terminology"; consequently, they lose confidence and felt embarrassed in front the audience. Generally, group members repeatedly mentioned self-confidence as a barrier at many stages in discussion. This can be considered as the main barrier to their oral communicative skills especially in line with the oral presentation skills. 


\subsubsection{Anxiety}

A number of participants mentioned that anxiety was also considered as the barriers to be overcome for them. One participant added that due to anxiety, he mumbles and cannot speak with friends or even relatives. They defined anxiety as "state of mind in which we face uneasiness"; hence, the effect of anxiety seemed as a general barrier during oral presentations.

“....anxiety are some of our problems indeed sir. I can communicate with someone in relatives or friends but when my cousins came from the USA, I faced problem in communicating with them..., State of mind in which we face uneasiness is called anxiety." (5/8).

Most participants agreed that there are certain concerns. As one of them shared his feelings and stated as: "feel anxious during presentation" (7/8). Additionally, another participant shared that he felt anxious and embarrassed during oral presentations. Thus, it has been discovered after groups' discussion repeated several times that anxiety is a barrier to their oral communication more as compared to their oral presentations. One participant noted:

“...I feel anxiety and low confidence ..., due to this problem I feel embarrassed." (1/8).

\subsubsection{Hesitation}

For participants, hesitation was another barrier that hindered their oral presentation performance as most participants agreed and collectively responded as:

"...we face problems in oral communication; we should communicate in English with friends even if we hesitate to talk in English." (7/8).

However, other participants believed that no matter what barriers they are facing, can be surmounted if they kept communicating in English. As one participant below mentioned that they need to develop interpersonal communication first instead of thinking what to do or what not to do. In this way, they lose their concentration and feel hesitation during communication of their thoughts with others. Two of them stated:

"...we communicate within ourselves what should I do and what should I not. This is because we have no practice till our intermediate classes, so we hesitate to communicate with others." (7/8).

Another participant echoed the feelings of the participant above explaining as:

"I find is to present something like presentations I hesitate during presentations." (1/8).

\subsubsection{Inferiority Complex}

Responses of the participants revealed that confusion occurs if they encounter a participant(s) who possess "more proficiency" while communicating in English. Moreover, one participant felt under pressure when respondent has effective oral skills. All participants frequently talked about inferiority complex issue.

"My problem is that one who has more proficiency in English I feel confused and pressurized before him and sometimes it is vice versa one who possesses lower proficiency than me I speak confidently." (6/8).

Keeping the momentum on of the discussion, the participants exchanged opinions in an intense emotional state that they lacked the ability of effective communicators in front of those who were of "higher proficiency" in English language. Ultimately, it led them into the inferiority complex which definitely created hindrances for them at the time of oral presentations. One participant stated:

"We have lack of confidence, we cannot communicate we feel shy when we communicate with people who are of higher proficiency in English..., the main factor that creates problems is confidence." (6/8).

On the contrary, one participant stated that he is facing barriers while communicating in English with others who possess more effective oral skills. The other participant stated that he used to get more confused to face off a speaker whose accent "is native like". Hence, it was found that undergraduates were under great stress due to inferiority complex during communication in particular oral presentations. One participant said:

“...indeed, we face problem when we communicate with more potent or people whose accent is native like." $(6 / 8)$.

Other participant shared:

"I also faced inferiority complex when I communicated with my cousins who were from the USA. Or if I get chance to speak to the native speakers of English I feel embarrassed, I fail to communicate. Once I was in a restaurant and manager wanted to get feedback about the food, I was feeling pressurized when manager spoke in English." (1/8). 
It should be noted from the shared story that native speakers or native-like accent creates more sense of inferior before his own cousins due to their native accent. Further, he felt embarrassing before them. Another participant emphatically said that due to criticism from people, they are surrounded with one of reasons too. He eloquently said, "Society does not appreciate" for English speaking rather they "discourage". One said:

"Our society's critical behaviour is one of the main reasons. Society does not appreciate rather discourage us to communicate in English." (5/8).

Verbatim of participants suggest that inferior complexity is not only seen as a barrier rather than more it can be turned into a moment of embarrassment if they fail to communicate effectively.

\subsection{Social Perceived Barriers}

\subsubsection{Lack of Interest}

Mentioned earlier by the participants that they lacked interest in oral communicative skills, it is because of environment. They shared that when they are trying to communicate in English language, their classmates and people surrounding to them made fun of them or gaze them with queer eyes. One participant echoed that he had no good experience of speaking English in such environment; therefore, he kept insisting on to devise communicative sessions for improving their interest in oral presentations.

“...when we speak English, people make fun of us... So I do have not had such good experience so far learning English. I request teachers to have communicative classes." (5/8).

During discussion, one of the participants explained how he lacked interest that is one the barrier that created more troubles for them during oral presentation. Moreover, reset of the participants stated their ideas that they do not feel uncomfortable because in past and present academic years classes had remained teacher-centered. Another participant highlighted that teachers' role is of great importance who create communicative classes. One of the participants stated:

"...our class environment is that those who have good communication skills are proud of it and rests of students sit back. I think teacher's role is of importance, teachers should have discussions or communicative classes. It is the teacher who encourages/motivates learners to speak in English I think sir I don't feel comfortable in CS classes because we (students) are mere passive listeners during classes." (7/8).

Further, one participant said that it was not only on teaching but they (pupils) also lack more interest than anyone else. Moreover, they lacked interest due to criticism and hardly get a positive feedback from their fellows; resultantly, they lack interest in oral presentations and other communicative activities. One participant asserted:

"...there is lack of interest from both audience and teachers. We want to participate but to the aforesaid issues we lack our interest and do not get constructive response from teachers and audience." (7/8).

Though, it is not a normal to hear from participants as shared one of them which make situation more vivid that unwillingness on the pupils' part which compelled them to participate in oral presentations. Most of them expressed their concerns related to opportunities which they are not provided to them for improvisation of oral presentation skills. Hence, they avoid participating in oral presentations because they had no or less opportunities to practice and properly get trained. One participant indicated:

"Majority of us avoids delivering presentations, we are reluctant to participate, and this is because we have not been given any proper platform for such activities. We are hesitating to participate in oral presentations because we have no proper platform." (7/8).

To summarise, it can be stated that most participants lacked interest because they "do not get constructive response" and they had "no proper platform". On the whole, participants had shown consent that they lack interest which is because of fewer chances and due to low motivation from peers and surroundings.

\subsubsection{Inadequate Educational Background}

Inadequate educational background has been seen a common barrier throughout intercourse. Four of group members belonged to countryside and their medium of instruction mostly remained local languages so as they found problematic to communicate to deliver oral presentations in English. One participant opined:

"In our university students are from interior areas and their base is from Sindhi medium and students' interest is low. Our primary educational level is not good so we have some problems in English." (4/8).

Participants during discussion repeated this barrier consistently and found it as a major cause of their poor performance during oral presentation. As one participant, echoing the sentiments of other participants stated: 
"Our primary level is not stronger...many of us study in government institutes and there is no practice. One of the reasons for this is our educational background." (4/8).

During discussion, participants expressed their concerns for inadequate education background which affected their performance while oral presentations. They thought due to division in educational sectors, more negative effects prevailed on their academia. Most of them held responsible to the segregated education system and government sector institutes where there is no or least concept of conducting oral presentations.

\subsubsection{Lack of Environment}

Overwhelmingly, lack of environment was discussed in a variety of ways. Most participants referred about the lack of environment in their university. Most participants stated that they preferred communicating in English but as they went out of the classroom, they switch to local language. On the basis of shared opinions, it can be said that participants were in serious need of useful English-speaking environment for developing their oral skills specifically oral presentations. One participant asserted:

“...we preferred speaking English during these classes of Functional English and Communication Skills but when we go out with friends out of the classes we talked in Urdu, Sindhi, or any other language." (8/8).

However, one participant went on saying that his university's environment for learning (learning here meant communicating) English "is not satisfactory". The same participant put this responsibility on his teachers by saying it is "totally on teachers" how they manage their classroom environment. This participant stated:

"...environment according to me is not satisfactory for learning English, in my opinion my first semester was satisfactory and second is good. It is totally on teachers. For me environment is zero." (8/8).

Generally, from this perspective of participants in focus group, lack of environment was one of the key barriers to oral presentations. They emphasised for more interactive classes and they disappointedly stated that their English "is getting worse due to no or very low environment" in this university. The participant opined:

"There is no environment of English here in our university...There should be interactive classes, however,

English is getting worse of mine due to no or very low environment." (8/8).

It is noteworthy, that on many occasions, participants expressed their concerns for lacking environment to communicate in English in their university. One participant worried and stated that he was unable to manage his English speaking due to lack of environment.

\subsubsection{Unfamiliar Audience}

Unfamiliar audience is also acknowledged as one of the main barriers. The participants discussed it as a difficult task to deal with oral presentations and they felt pressurized, tensed, and anxious while communicating in the presence of unknown audience. One participant noted:

"We feel pressure, tension and anxiety; I face many difficulties in conversation not with friends or family members but with unfamiliar participants/audience." (6/8).

One participant voiced his frustration of facing problems at the time of oral presentations. He confessed that due to continuous talk in front of audience made him worried. Further, he revealed that he asked his best friends to go out of class during presentation as "they make fun or tease" to each other; similarly, other group members also nod their heads and agreed with him. He said:

"I think presentations are problematic for me because there is no break and you are facing audience, you do not have thinking time while presentations. I think best friends should be out of the class when presentations are on, because they make fun or tease you while presenting." (7/8).

Another participant shared:

“...I lose confidence when I speak in front of audience, and I feel problem to have eye to eye contact and cannot explain the topic before audience... Confidence level is higher when I sit on the chair but when I come to stage I lose my confidence." (6/8).

The participants clearly suggested that unfamiliarity with audience is the barrier for them. They could not maintain direct eye contact and speak on the presentation topic. They confessed an interesting fact that they become more comfortable and confident when they are sitting on the chair instead of coming before audience. More reasons were shared by one the participant who faced same problems as the whole audience looks at the presenter. He represents all participants and said as "some students have stage fright" as they do not like presentations as a healthy activity, rather "they remain silent, their legs shiver" and they avoid oral presentations in class. One opined: 
"...you become center of audience's attention therefore; I cannot communicate my ideas effectively... Audience's attitude is not encouraging. However, some students have stage fright, they do not like this activity of presentations and they have built kind of phobia. Consequently, they remain silent, their legs shiver and they shy during classes."

"Many times I delivered presentation but my legs shivered when I came in front of audience first time. Thereafter, to some extent I have a kind fear of audience, because whole audience is looking at me... I was unfamiliar with audience so I had problems that time." (6/8).

Above response suggested that unfamiliar audience creates a troublesome situation; therefore, these respondents remain reluctant to participate in oral presentations. Hence, it can be said that participants need greater amount of opportunities to tackle this barrier during oral presentations.

\subsection{Linguistic Perceived Barriers}

\subsubsection{Low Vocabulary}

As the discussion moved on, the participants shared about shortage of vocabulary, nearly all of them found low Vocabulary is a barrier that increases their problems during oral presentations. They seemed troubled to express their ideas during discussion and showed their apprehensions on the vocabulary problem. One participant stated that "vocabulary is problem for me" when was asked about the problems to be faced. He further added, "We do not communicate" a lot in English because of the lacked vocabulary. Other participant believed that one can communicate frequently if he improves his vocabulary and remembers all those difficult terms for longer period of time. One participant stated:

"...we have some problems in English such as our vocabulary. We have vocabulary issue."

"Vocabulary is problem for me sir but we do not communicate a lot so we lack vocabulary. We should communicate more in English with people so by communicating we can improve vocabulary." (8/8).

Most participants explained in detail by raising their voice that they can communicate effectively if "our vocabulary" were richer. Another participant sitting next to him endorsed the point and stated as "no doubt vocabulary is a problem" but he insisted that they can communicate in English in order to develop their oral skills. One participant below noted:

"...we can communicate but our vocabulary level is low, and so is the environment also."

"No doubt vocabulary is a problem but we should also communicate in English with friends frequently. Yes, we need vocabulary indeed and it matters." (8/8).

\subsubsection{Lack of Knowledge}

Lack of knowledge also was described as barrier during oral presentations; one participant stated as "we feel lower in confidence". The main reason for "we lack knowledge' was poor vocabulary. These participants believed if they had more knowledge they can communicate more effectively. These participants noted:

"...we feel lower in confidence because we lack knowledge, if we possess good knowledge we can communicate fluently and efficiently." (7/8).

Another participant interrupted other focus group members shared his problem as:

“...question and answer session especially during presentation. Why? Because we need to build ideas and deliver them spontaneously, if we have ideas we can reply and can communicate our ideas. In other words, I think lack of knowledge is problem too for me." (1/8).

In the above statements, one participant said that he faced problems during oral presentations in particular at the time of question-answer session of presentation. He stated that they need to construct ideas and communicate them spontaneously in front of audience; this situation needs more knowledge to deal with. He believed that "lack of knowledge was problem" for him and others also agreed with this participant. He said:

"Our knowledge is lower so we face problems during presentations and consequently we lose our confidence."

“...we lack knowledge when we deliver presentations...all of us have identified confidence problem." (7/8).

This barrier to oral presentation was described by almost all participants due to lack of knowledge they cope with misunderstandings which result in some embarrassing situations and lowered their self-confidence. As focus group participants said "our knowledge is lower" because of it they are coping with problems during oral 
presentations.

\subsubsection{English as a Barrier}

English language itself has become a barrier to these participants. They conceal their weakness before audience and compensate with code-switching. Interestingly, other participants preferred to use the term "fluctuations" in the speech rather problems. He revealed further about term that he could not "say proper sentences" but he insisted he can communicate his thoughts only instead of proper sentence arrangements. He defined term fluctuations here mean as "problems or barriers" and he echoed that he was facing problems due to English language. he noted:

“...I can communicate but there would be some fluctuations in my speech, such as I cannot say proper sentences however, I may be able to communicate my thoughts. By fluctuations I mean problems or barriers and of course I am facing problems." (5/8).

English language was not seen as a barrier for all participants rather it was a barrier for some members. Consequently, those participants avoid to communicate in English either it is class or public place.

\section{Discussion and Conclusion}

The findings of this study concur with previously conducted researchers in different contexts. Oral presentation skill needs a serious attention from academia, as Alam et al. (2013) focused on improvisation of oral skills of Pakistani students and opined that little or no exposure to English language, fear, and anxiety along with the lack of environment and opportunities which were found as the main factors or hindrance to deal performance of oral communicative skills. Zivkovic (2014) laid emphasis on oral presentations which are growing significantly as a vital component of teaching language, in particular in the tertiary environment. Additionally, present challenges to economic situation demand students to possess and enhance subjects-knowledge for their prospective employer (Follows \& Steven, 2000). Importance of oral presentation has been highlighted at workplace environment along with technical expertise (Kakepoto et al., 2012; Schnell, 2006; Markes, 2006).

The findings of this research work confirm the three categories that include perceived barriers psychological, social and linguistic. The study explored oral communication apprehensive factors prevailing among Pakistani undergraduates; the study also investigates how oral presentation in particular was affected. The three emerged categories to Pakistani undergraduates are particularly of great importance for engineering communication practitioners, instructors and language teachers. On the basis of findings, it is concluded that peer pressure, low confidence, anxiety, hesitation, low motivation, inferiority complex, lack of interest, poor educational background, lack of environment, unfamiliar audience, English language as a barrier, lack of vocabulary, and lack of knowledge are the main barriers that hinder Pakistani undergraduates to their oral presentation skills. Consequently, the presence of these barriers affects undergraduates' performance. Providing ample practice opportunities for the development of effective oral presentation skills, there should be more student-centric activities to be devised. Vitality and knowledge of oral presentation skills can be obtained through organization of workshops. There is also a need for more interactive sessions to focus on trainings. Revision and addition of subjects should be incorporated in curricula to emphasize oral presentation skills. Furthermore, more emphasis is needed on English for Specific Purposes, in order to enhance undergraduates, their English language proficiency, and presentation skills. The faculty members and universities should take some appropriate measures to enable Pakistani undergraduates to develop and enhance undergraduates' abilities in order to ensure the needs of industries.

\section{Limitations}

The sample size is not whole representation of common population of engineering undergraduates. However, urban and rural backgrounds were not taken in to account due to the short span of time.

\section{References}

Adams, A., \& Cox, A. L. (2008). Questionnaires, in-depth interviews and focus groups. In P. Cairns \& A. L. Cox (Eds.), Research Methods for Human Computer Interaction (pp. 17-34). Cambridge, UK: Cambridge University Press. https://doi.org/10.1017/CBO9780511814570.003

Alyan, A. A. (2013). Oral Communication Problems Encountering English Major Students: Perspectives of Learners and Teachers in Palestinian EFL University Context. AWEJ, 4(3), 226-238.

Aly, I., \& Islam, M. (1995). Factors affecting oral communication apprehension among business students: An empirical study. The Journal of American Academy of Business, 2, 98-103.

Anderson, G. (1990). Fundamentals of educational research. London: The Falmer Press. 
Asuncion-Lande, N. C. (1998). English as the dominant language for intercultural communication: Prospects for the next century. In K. S. Sitaram \& M. H. Prosser (Eds.), Civic discourse: Multiculturalism, cultural diversity and global communication (pp. 67-81). Stamford: Ablex Publishing Corporation.

Barry, A. (1998). Student reticence and oral testing: A Hong Kong study of willingness to communicate. Communication Research Reports, 15(2), 162-169. https://doi.org/10.1080/08824099809362110

Baum, E. (2000). Engineering accreditation in the United States of America - Criteria. Proc. 2nd Global Congress on Engng. Educ., Wismar, Germany.

Bhattacharyya, E., Shahrina, M. N., \& Rohani, S. (2009). Internship students'workplace communication skills: Workplace practices and university preparation. Paper presented at the CIEC Conference, Florida, Orlando, USA.

Borzi, M. G., \& Mills, T. H. (2001). Communication apprehension in upper-level accounting students: An assessment of skill development. Journal of Education for Business, 76(4), 193-199. https://doi.org/10.1080/08832320109601310

Brown, G., \& Yule, G. (1983). Discourse analysis. Cambridge: Cambridge University Press. https://doi.org/10.1017/CBO9780511805226

Byrne, D. (1986). Teaching Oral English. England: Longman.

Du-Babcock, B. (2000). A model of expatriate on-the-job adaptation to overseas assignments: A communication perspective. Journal of Asia Pacific Business, 2(4), 39-58. https://doi.org/10.1300/J098v02n04_04

Ellis, R. (2003). Task-based language learning and teaching. Oxford: Oxford University Press.

Fallows, S. \& Steven, C. (2000). Building Employability Skills into the Higher Education Curriculum: A $\begin{array}{llll}\text { University-wide Initiative. Education } \quad \& \quad \text { Training, } & \text { 42(2), }\end{array}$ https://doi.org/10.1108/00400910010331620

Frantz, J., Marlow, A., \& Wathen, J. (2005). Communication Apprehension and its Relationship to Gender and College Year. Journal of Undergraduate Research at Minnesota State University, 5, 7. Retrieved from https://cornerstone.lib.mnsu.edu/jur/vol5/iss1/7

Guest, G., Namey, E., \& Mitchell, M. (2013). Collecting qualitative data: A field manual for applied research. Thusand Oaks, CA: Sage. https://doi.org/10.4135/9781506374680

Greg, G., Emily, N., Jamilah, T., Natalie, E., \& Kevin, M. (2017). Comparing focus groups and individual interviews: findings from a randomized study. International Journal of Social Research Methodology, 20(6), 693-708. https://doi.org/10.1080/13645579.2017.1281601

Hassan, R. (2009). Teaching Writing to Second Language Learners. iUniverse, Bloomington, IN 47403. USA.

Holstein, J. A., \& Gubrium, J. F. (1995). The Active Interview: Qualitative Research Methods (vol. 37). Thousand Oaks, CA: Sage. https://doi.org/10.4135/9781412986120

Jamshidnejad, A. (2011). Developing accuracy by using oral communication strategies in EFL interactions. Jouranl of Language Teaching and Research, 2(3), 530-536. https://doi.org/10.4304/jltr.2.3.530-536

Jamshidnejad, A. (2010). The construction of oral problems in an EFL context: An innovative approach. Studies in Literature and Language, 1(6), 8-22.

Kakepoto, I., Habil, H., Omar N. A. M., \& Said, H. (2012). Professional Presentations: Factors that Influence Oral Presentations of Engineers in Engineering Workplace of Pakistan. Journal of Economics and Sustainable Development, 3(13), 128-131.

Kang, Y., \& Cheng, X. (2013). Teacher learning in the workplace: A study of the relationship between a novice EFL teacher's classroom practices and cognition development. Language Teaching Research, 18(2), 169-186. https://doi.org/10.1177\%2F1362168813505939

Khan, S. (2010). Strategies and spoken production on three oral communication tasks: A study of high and low proficiency EFL learners. A doctoral thesis submitted to the Universitat Autonoma de Barcelona. Retrieved May 17, 2018, from http://www.tdx.cat/bitstream/handle/10803/32083/sk1de1.pdf;jsessionid=A1E58E613061BB8CC104C228E 83EA643.tdx2?sequence $=1$

Khan, N., \& Ali, A. (2009). Improving the speaking ability in English: The students' perspective. Precedia Social and Behavioural Sciences, 2, 3575-3579. https://doi.org/10.1016/j.sbspro.2010.03.554 
Kitao, K. (1996). Why do we teach English? The Internet TESL Journal, 2(4), 1-3. Retrieved from http://www.aitech.ac.jp/ iteslj/

Kitzinger J. (1995). Introducing focus groups. British Medical Journal, 311, 299-302. https://doi.org/10.1136/bmj.311.7000.299

Krueger, R. A. (1994). Focus groups: the practical guide goes applied research (2nd ed.). Thousand Oaks: SAGE Publications.

Lindsay, C., \& Knight, P. (2006). Learning and teaching English: A course for teachers. Oxford: Oxford University Press.

Lucas, S. E. (2001). The art of public speaking (7th ed.). Boston, MA: McGraw-Hill.

Margarita, T. (2008). Depression and Anxiety among College Students. Psych Central. https://doi.org/10.1186/1471-2458-7-347

Markes, I. (2006). A review of employability skills needs in engineering. European Journal of Engineering Education, 31(6), 637-650. https://doi.org/10.1080/03043790600911704

McCroskey, J. (1970). Measures of Communication-bound Anxiety. Speech Monographs, 37, 269-277. https://doi.org/10.1080/03637757009375677

McCroskey, J. (1982). Oral communication apprehension: A reconceptualization. In M. Burgoon (Ed.), Communication Yearbook 6 (pp. 136-170). Beverly Hills, CA: Sage.

McCroskey, J. (1984). Avoiding communication. California: Sage.

McCroskey, J. C., Gudykunst, W. B., \& Nishida, T. (1999). Communication Apprehension among Japanese Students in Native and Second Language. Department of Communication Studies, West Virginia University, U.S.

Miles, M. B., \& Huberman, A. M. (1994). Qualitative data analysis: An expanded Sourcebook (2nd ed.). Thousand Oaks: Sage Publications.

Mortensen, C. D. (1972). Communication: The Study of Human Communication (Chapter 2, "Communication Models"). New York: McGraw-Hill Book Co.

Morreale, S. P., Osborn, M. M., \& Pearson, J. C. (2000). Why Communication is Important: A Rationale for the Centrality of the Study of Communication. Journal of the Association for Communication Administration, $29,1-25$.

Nunan, D. (1991). Language Teaching Methodology. Great Britain: Prentice Hall International (UK) Ltd.

Price, M. L. (1991). The Subjective Experience of Foreign Language Anxiety: Interviews with Highly Anxious Students. In E. K. Horwitz \& D. J. Young (Eds.), Language Anxiety. Englewood Cliffs, New Jersey: Prentice Hall

Richards, J. C. (2006). Communicative Language Teaching Today. New York: Cambridge University Press.

Richards, J., \& Renandya, W. (2002). Methodology in language teaching. Cambridge: Cambridge University Press. https://doi.org/10.1017/CBO9780511667190

Riemer, M. J. (2007). Communication Skills for the 21st Century Engineer. Global Journal of Education, 11(1). Published in Australia.

Schnell, L. M. (2006). Work in progress: Impacting global engineering education for new college graduates (pp. 28-31). Paper presented as ASEE/IEEE Frontiers in Education Conference. San Diego, California.

Rubin, H. J., \& Rubin, I. S. (1995). Qualitative Interviewing: The Art of Hearing Data. Thousand Oaks, CA: Sage.

Singh, M. K. M., David, A. R., \& Choo, J. C. S. (2011). Communication Apprehension among International Undergraduates: The Impact on their Communicative Skills. Modern Journal of Language Teaching Methods, 1(2).

Staab, C. (1992). Oral language for today's classroom. Markham, Ontario: Pipping Publishing.

Stuckey, H. L. (2014). The first step in Data Analysis: Transcribing and managing qualitative research data. $J$ Soc Health Diabetes, 1(2), 6-8. https://doi.org/10.4103/2321-0656.120254

Thaher, M. (2005). Communication Apprehension among An-Najah National University Students. An-Najah 
Univ. J. Res. (H.Sc.), 19(2).

TIRF. (2009). The impact of English and plurilingualism in global corporations. Retrieved May 10, 2018, from http://www.tirfonline.org

Tunaboylu, O. (1993). Speaking Through Association. FORUM, 31(2), 47-48.

Verapornvanichkul, P. (2011). A Survey of Problems in Oral Communication Skills when dealing with English Speaking Clients: A case study of employees at one of the big 4 audit firms in Thialand. MA. Dissertation.

$\mathrm{Xu}, \mathrm{T}$., \& Du-Babcock, B. (2012). Impact of English-language proficiency on Chinese expatriates' adjustment to overseas assignments. Global Advance in Business Communication, 1(1), 64-80.

Ya-Ni, Z. (2007). Communication strategies and foreign language learning. US-China Foreign Language, 5(4), $43-47$.

Yasmin, H. Z. (2003). English Language Needs of Polymer Engineering Undergraduate Students in FKKSA, UTM: As Perceived by the Learners, Lecturers, and Employers. Master's thesis, Universiti Teknologi Malaysia, Skudai. Retrieved May 25, 2018 from http://merr.utm.my/8555/

Zivkovic, S. (2014). The Importance of Oral Presentations for University Students. Mediterranean Journal of Social Sciences, 5(19). https://doi.org/10.5901/mjss.2014.v5n19p468

\section{Copyrights}

Copyright for this article is retained by the author, with first publication rights granted to the journal.

This is an open-access article distributed under the terms and conditions of the Creative Commons Attribution license (http://creativecommons.org/licenses/by/4.0/). 